\title{
STUDIES OF THE FAUNA OF PERCOLATION WATER OF HUDA LUKNJA, A CAVE IN ISOLATED KARST IN NORTHEAST SLOVENIA
}

\author{
RAZISKAVE FAVNE PRENIKLE VODE: PRIMER JAME \\ HUDA LUKNJA NA PODROČJU OSAMELEGA KRASA V \\ SEVEROVZHODNI SLOVENIJI
}

\author{
Tanja PIPAN ${ }^{1}$, Vesna NAVODNIK ${ }^{2}$, Franc JANŽEKOVIČ ${ }^{3}$, Tone NOVAK ${ }^{3}$
}

\begin{abstract}
UDC 556.34:59(497.4-18)

Tanja Pipan, Vesna Navodnik, Franc Janžekovič \& Tone Novak: Studies of the fauna of percolation water of Huda luknja, a cave in isolated karst in northeast Slovenia

The fauna and community ecology of percolation water was studied using monthly samples of 12 drips in the Medvedji rov in the cave Huda luknja. This is the largest cave system in the so-called isolated karst which consists of limestone patches of $<1$ to $10 \mathrm{~km}^{2}$ in size in central and northeastern Slovenia. Huda luknja is developed in one of these patches measuring about $1 \mathrm{~km}^{2}$ in the Triassic limestones-the Paka karst. The research focused on the investigation of the epikarst fauna in NE Slovenia. Temperature, conductivity, hardness and concentrations of various ions in water were measured. Considerable spatial and temporal variation in parameters existed among the drips. However, there was no correlation between the community structure and the parameters. There are six aquatic species and 19 terrestrial species in the epikarst of the Paka isolated karst. In the drips, individuals of epigean, epikarstic and hypogean aquatic taxa as well as terrestrial taxa belonging to the same groups as those in caves in the Dinaric karst were found. Unlike the Dinaric karst, the most abundant group was oligochaetes, not copepods. In general, the biotic diversity diminished from the entrance to deep in the cave. More investigation in the isolated karst is required to decide either this is the specific characteristic of this karst patch or a general phenomenon of isolated karst.

Key words: isolated karst, epikarst, percolating water, biospeleology, fauna.
\end{abstract}

Izvleček

UDK 556.34:59(497.4-18)

Tanja Pipan, Vesna Navodnik, Franc Janžekovič \& Tone Novak: Raziskave favne prenikle vode: Primer jame Huda luknja na področju osamelega krasa v severovzhodni Sloveniji

$\mathrm{Z}$ mesečnimi vzorčevanji smo eno leto proučevali favno in ekologijo združb v 12 curkih prenikle vode v Medvedjem rovu Hude luknje pri Doliču. To je največji jamski sistem tako imenovanega osamelega izoliranega krasa, ki sestoji iz manj kot $1 \mathrm{~km}^{2}$ do več kot $10 \mathrm{~km}^{2}$ velikih apnenčastih zaplat. Huda luknja je razvita v eni od teh krp, ki meri okrog 1 km², imenovani Paški kras, v triasnih apnencih. Osredotočili smo se na raziskave epikraške favne. Spremljali smo letno dinamiko vrednosti temperature, prevodnosti, trdote in koncentracije različnih ionov. $\mathrm{V}$ teh fizikalnih in kemijskih parametrih so se curki značilno razlikovali med seboj, prav tako voda istih curkov med letom. Med združbami in parametri ni bilo korelacije. V curkih zajeti osebki so bili naključno razporejeni in so pripadali tako vodnim kot kopenskim površinskim, epikraškim in podzemeljskim taksonom. Zastopane so bile iste skupine organizmov kot v jamah Dinarskega krasa, vendar so prevladovali maloščetinci, ne ceponožci. Na splošno je vrstna pestrost organizmov upadala od prvega vzorčevalnega mesta proti notranjosti. Epikraška vodna favna je v Paškem krasu slabo zastopana, vendar ni jasno, ali je to značilnost te kraške krpe ali celotnega osamelega krasa, zato so potrebne dodatne raziskave na osamelem krasu.

Ključne besede: osameli kras, epikras, prenikajoča voda, biospeleologija, favna.

\footnotetext{
${ }^{1}$ Karst Research Institute, Scientific Research Centre of the Slovenian Academy of Sciences and Arts, Titov trg 2, p.p. 59, SI-6230, Postojna, Slovenia, E-mail: pipan@zrc-sazu.si

${ }^{2}$ Florjan 210a, SI-3325, Šoštanj, Slovenia

${ }^{3}$ Department of Biology, Faculty of Natural Sciences and Mathematics, University of Maribor, Koroška 160, SI-2000, Maribor, Slovenia, E-mail: tone.novak@uni-mb.si, franc.janzekovic@uni-mb.si
}

Received/Prejeto: 01.11.2007 


\section{INTRODUCTION}

In Slovenia, karst comprises $44 \%$ of its land surface (Gams 2004) with more than 9000 caves registered to date (Cave register IZRK ZRC SAZU, Speleological Association of Slovenia). According to geological, hydrological and speleological characteristics the karst in Slovenia is divided into three groups (Habič 1969): (1) Alpine karst with high mountain karst, (2) Dinaric karst, divided in high and low karst, and (3) intermediate Dinaric-Alpine and isolated karst. The isolated karst is represented by shallow patches of limestones and dolomites of different ages and is further divided into several isolated subunits. Each of them differs from the others in its size, structure of carbonate rocks and hydrology (Habič 1969, Habe 1972).

The evolution of particular karst areas can be, beside their geological, geomorphological and hydrological characteristics, reflected also in specific distributional patterns and diversity of the hypogean fauna. Some basic biogeographical studies have been made to explain the processes occurring in the Slovenian karst, mainly on Gastropoda and Crustacea (Bole 1972, 1977, 1985, Sket 1993, 1999a, b, 2002, Sket et al. 2004a, Culver et al. 2003, Culver \& Pipan 2007) and on highly endemic attemsiid diplopods (cf. Mršić et al. 1996). Recently, phylogeographic approaches and molecular techniques were used to explain the evolution of troglobionts in the Dinaric karst in connection with the historical events within the area (Trontelj et al. 2007). In the isolated karst, similar studies have not been carried out, although many biological investigations have been made in caves in northern and central Slovenia (Bole 1977, Novak 2005) but they have not been summarized. They are of considerable interest because they are analogous to islands, which play a very prominent role in biogeography in general (Culver \& Pipan in press).

In the last ten years, especially since 2000, the stygobiotic fauna from percolation water has been systematically investigated. It was found out that this habitat, called epikarst, is an biologically important habitat in its own right with a diverse, specialized fauna (Pipan 2005), as well as a transition zone between surface and cave water. This specialized fauna, represented mainly by copepods, has been intensively studied in Slovenia (Pipan
2005), and recently preliminary studies have been carried out in Romania (Moldovan et al. 2007), Spain (Camacho et al. 2006) and West Virginia, U.S.A. (Pipan \& Culver 2005, Pipan et al. 2006b, Fong et al. 2007). The epikarst fauna is also of special interest because it is easier to obtain quantitative samples and estimates of total species richness (Pipan and Culver 2007).

Epikarst, the "skin" of karst (Bakalowicz 2004), is the entry for most organic matter originating in soils into caves. In this way the percolating water entering into underground habitat is crucial for the hypogean organisms as a source of nutrients and as a reservoir of pollutants as well. There has been little direct investigation of the flux of nutrient resources in caves (Simon et al. 2007).

The isolated karst has not been investigated for the fauna of water trickles. One of its most northern patches is the so-called Paka isolated karst, named for the Paka River, which originates in the Eastern Alps. This is a floristically and faunistically interesting area inhabited by some disjunctively dispersed species, like Cortusa matthioli (Primulaceae), Waldsteinia ternata subsp. trifolia (Rosaceae), and endemics, like the hypogean beetle Aphaobiella tisnicensis Pretner 1949, the spider Troglophyphantes diabolicus Deeleman-Reinhold 1971 and others (Pretner 1949, Batič et al. 1980, Novak \& Kuštor 1982, Sket 1994, Presetnik \& Hudoklin 2005, Zagmajster \& Kováč 2006). Tisnik hill (786 m a.s.l.) in the Paka isolated karst is with its 17 described caves among the most karstified areas in Slovenia; many of these caves are documented also as archaeological and/or Palaeolithic sites (Kocbek 1895, Polscher 1917, Brodar 1938, Ravljen 1986, 1989, Brodar 1993, Gams 2004). All these make this region of interest also for the investigations of the epikarst biodiversity.

In this paper we report on the first results of the biotic diversity and the ecology of fauna from percolation water in the isolated karst of NE Slovenia. We compare it to a previous study of the epikarst fauna in the karst heartland of Slovenia (Pipan 2005), and report on the physical and chemical characteristics of the percolating water in Huda luknja.

\section{RESEARCH AREA AND METHODS}

The investigations were carried out in the cave Huda luknja pri Gornjem Doliču (Cadastre Number 413, Cave register IZRK ZRC SAZU, Speleological Association of Slovenia) situated in the hill Tisnik. Its main, lower entrance opens at $503 \mathrm{~m}$ a.s.l. at the bottom of the hill while its upper entrance - the swallet Ponor Ponikve at 


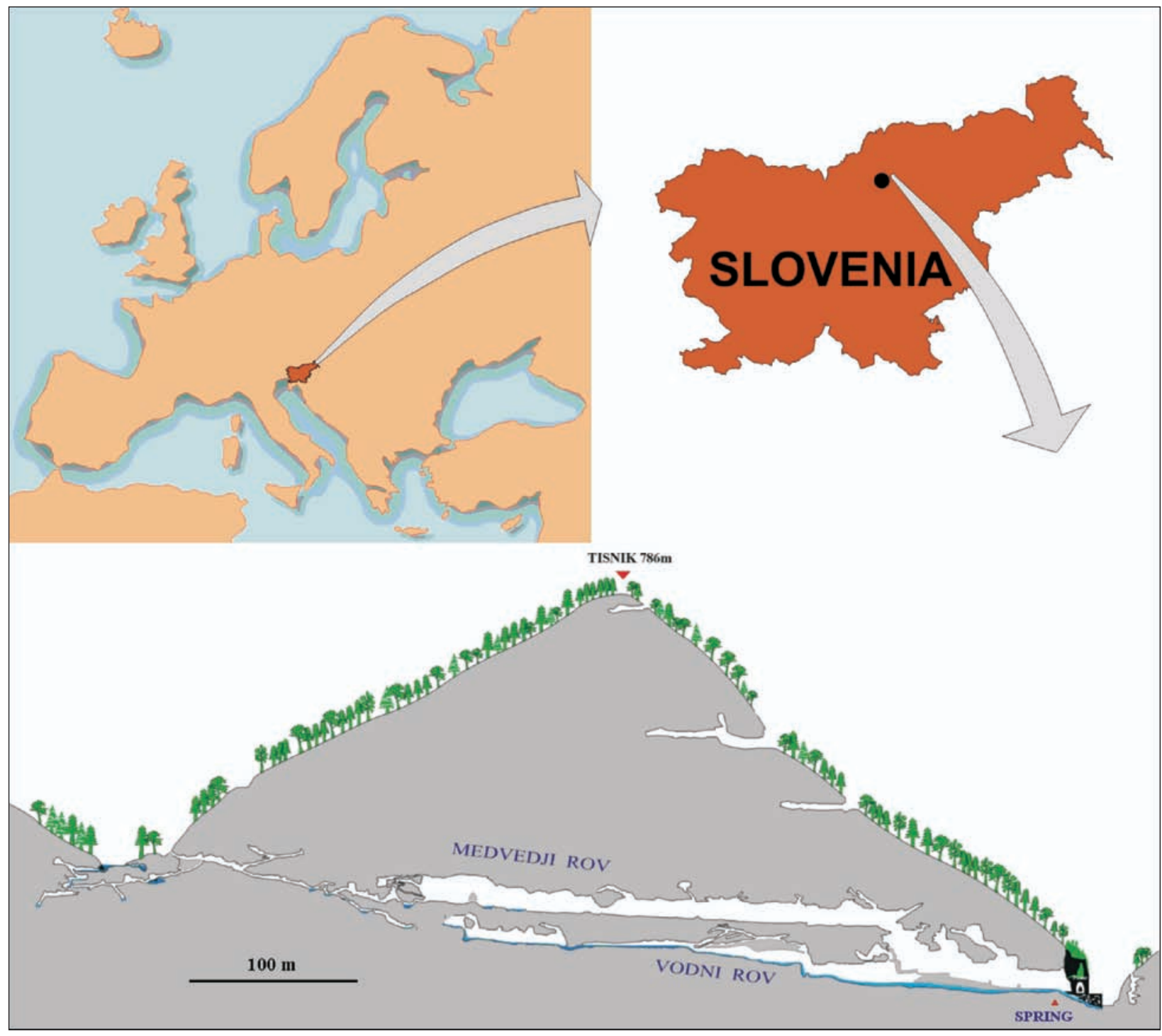

Fig. 1: Geographical location and the longitudinal section of the Huda luknja cave system; acc. to Ravljen (1986, 1989), completed by R. Bračič and M. Podpečan.

$622 \mathrm{~m}$ a.s.l. - is hardly ever accessible more than $35 \mathrm{~m}$ inside. The cave begins at the contact of non-karstic Miocene sandstone, conglomerate and marl, with middle and upper Triassic limestones where-in it is developed (Gospodaric 1980, Gams 2004). The cave consists of two main passages: the lower active and the upper dry $402 \mathrm{~m}$ long Medvedji rov. Above the swallet there is the Lisičnica cave, which was in the late 1980s connected with the Medvedji rov by pumping out water from a siphon in-between (Fig. 1) providing an accessible cave system through the hill. With its total length of $2339 \mathrm{~m}$, this is the longest cave system in NE Slovenia. Ponikva brook runs through the water passage, otherwise the karst aquifer in the hill Tisnik is recharged by diffuse infiltration of precipitation. The passage Medvedji rov was chosen for the sampling of percolation water (Fig. 2) because it provides different types of drips: those with a permanent current, such providing dropping water and those immediately reacting to precipitation. Twelve drips in a linear distance of ca. $190 \mathrm{~m}$ between the first and the last one were sampled monthly from November 2005 till October 2006.

Sampling of percolation water fauna was done using the method described in Pipan $(2003,2005)$. Water and animals were collected via a funnel which emptied into a plastic container, having aside overflow holes covered with a net (mesh size $60 \mu \mathrm{m}$ ) to retain the animals. Temperature $\left({ }^{\circ} \mathrm{C}\right)$, conductivity $\left(\mu \mathrm{Scm}^{-1}\right)$ and $\mathrm{pH}$ were measured using conductivity meter (ISKRA MA 5964) and pH meter (ISKRA MA 5740). Water samples for chemi- 


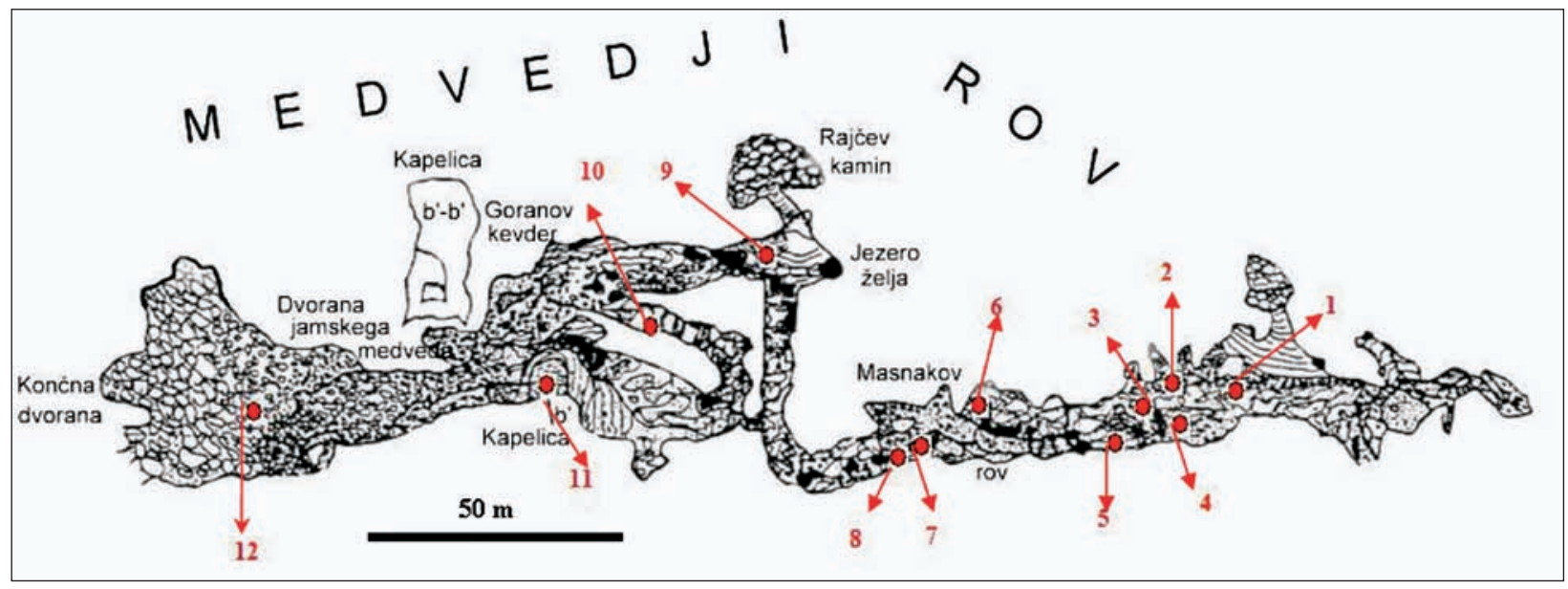

Fig. 2: Ground plan of the passage Medvedji rov in the Huda luknja cave system showing sampling sites; acc. to Ravljen (1986, 1989), completed by R. Bračič and M. Podpečan. Fig.

cal analyses were transported in the laboratory where concentrations of cations (sodium, potassium, calcium and magnesium) and anions (chloride, sulphate and nitrite) as well as calcium and total hardness were determined using Standard Methods for the Examination of Water and Wastewater (1989). The samples of fauna were in situ fixed with the formaldehyde until the final solution of $2-3 \%$. Organisms were extracted and identified using a microscope (Olympus CH30) and stored in 70\% ethanol.

Descriptive statistics was used to describe physical and chemical characteristics of the drips. The correlation between fauna assemblages and physical and chemical parameters of percolation water was performed calculating Pearson coefficient. One-way ANOVA was used in testing differences between the drips and the sampling dates in each physical and chemical parameter. In testing communities, the Simpson index of dominance $(D)(1)$ and the Shannon-Weaver diversity index $\left(H^{\prime}\right)(2)$ were calculated separately for each drip in the whole year. The Pearson correlation between $D$ and $H^{\prime}$, and the distance from the entrance and the surface, respectively, was calculated for all 12 drips. The Jaccard similarity coefficient
$\left(S_{r}\right)(3)$ was calculated separately for aquatic and terrestrial taxa to evaluate similarities of these communities in different drips (Legendre \& Legendre 2003):

$$
\begin{aligned}
& D=1-\sum\left(\frac{n_{i}}{N}\right)^{2} \\
& H^{\prime}=-\sum \frac{n_{i}}{N} \ln \frac{n_{i}}{N} \\
& S_{J}=\frac{a}{a+b+c}
\end{aligned}
$$

where $n_{i}$ is the number of individuals belonging to species $i, N$ the total number of individuals, $a$ the number of common species in both drips (joint occurrence), $b$ the number of species in one drip but not in the other, and $c$ the number of species in the second drip but not in the first one. The Jaccard index values were compared among each other using the Mantel t-test (program MANTEL for Windows), and the comparison of the index values between water and terrestrial taxa was performed as well. The program SPSS 11.0 was used in the statistical procedures.

\section{RESULTS}

The descriptive statistics of the physical and chemical parameters is presented in Table 1. Considering the whole year, there were significant differences between sampling sites in each physical and chemical parameter $\left(\mathrm{F}_{11,266}=1.90, p=0.039\right.$ for $\mathrm{pH}$ and $\mathrm{F}_{11,266}=2.41$, $p=0.007$ for temperatures, and $\mathrm{F}_{11,266}=5.10-71.73$, $p<0.001$ for the others) as well as in each parameter between dates $\left(\mathrm{F}_{11,266}=1.95, p=0.033\right.$ for total hardness, and $\mathrm{F}_{11,266}=3.09-360.13, p<0.001$ for the others). 


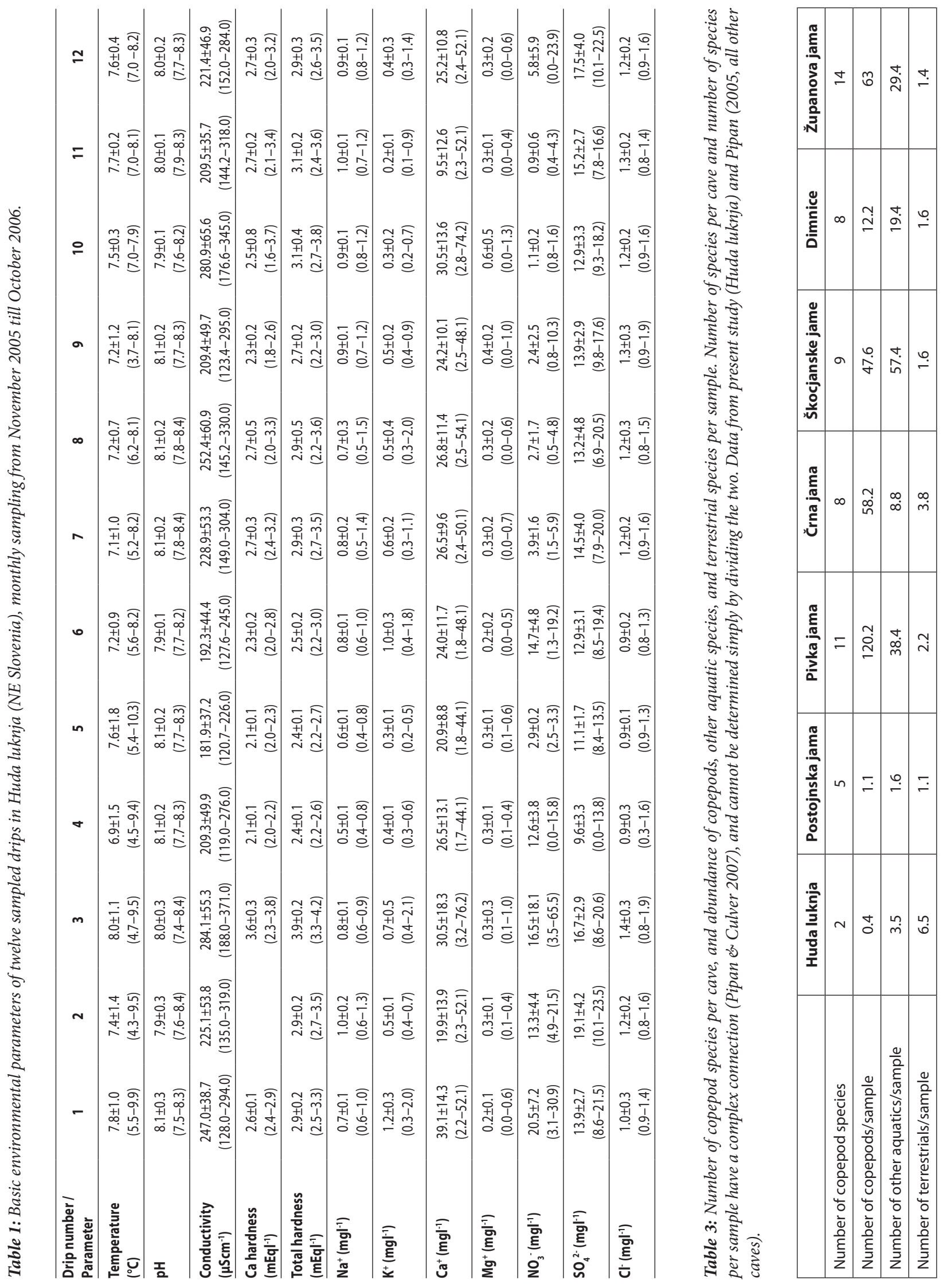


Table 2: List of taxa found in twelve drips during a one year sampling from November 2005 till October 2006 in Huda luknja (NE Slovenia)*.

\begin{tabular}{|c|c|c|c|c|}
\hline HIGHER GROUP & CLASS & ORDO & FAMILY & $\begin{array}{c}\text { GENUS and/or SPECIES } \\
\text { A amphibic, } T \text { terrestrial, AQ aquatic taxon }\end{array}$ \\
\hline NEMATODA & & RHABDITIDA & & unidentified, $A Q$ \\
\hline \multirow[t]{2}{*}{ ANNELIDA } & CLITELLATA & OLIGOCHAETA & Enchytraeidae & unidentified, $A Q$ \\
\hline & & & Lumbricidae & cf. Dendrobaena sp., A \\
\hline \multirow[t]{24}{*}{ ARTHROPODA } & ARACHNIDA & PALPIGRADI & Eukoeneniidae & $\begin{array}{l}\text { Eukoenenia cf. austriaca, } \mathrm{T} \\
\quad \text { (a tail fragment) }\end{array}$ \\
\hline & & ARANEAE & Linyphiidae & Troglohyphantes diabolicus, T \\
\hline & & ACARINA & Ixodidae & Ixodes vespertilionis, $\mathrm{T}^{* *}$ \\
\hline & & MESOSTIGMATA & & unidentified, $\mathrm{T}$ \\
\hline & & ORIBATIDA & & unidentified, $T$ \\
\hline & AMPHIPODA & & Niphargidae & Niphargus scopicauda, AQ \\
\hline & OSTRACODA & & & unidentified, $A Q$ \\
\hline & COPEPODA & HARPACTICOIDA & Parastenocarididae & Parastenocaris nolli alpina, AQ \\
\hline & & & Canthocamptidae & Bryocamptus balcanicus, AQ \\
\hline & CHILOPODA & & & unidentified, $\mathrm{T}$ \\
\hline & DIPLOPODA & ACHEROSOMATIDA & & unidentified, $T$ \\
\hline & & & Attemsiidae & Polyphematia moniliformis, $\mathrm{T}$ \\
\hline & INSECTA & ENTOGNATHA & & \\
\hline & & COLLEMBOLA & Poduridae & unidentified, $T$ \\
\hline & & & Sminthuridae & unidentified, $T$ \\
\hline & & & Entomobryidae & unidentified, $\mathrm{T}$ \\
\hline & & DIPLURA & Campodeidae & Plusiocampa sp., T \\
\hline & & PTERYGOTA & & \\
\hline & & COLEOPTERA & Staphylinidae & cf. Atheta sp., T \\
\hline & & & Carabidae & Laemostenus (Antisphodrus) schreibersi, T \\
\hline & & & Curculionidae & Otiorhynchus (Troglorhynchus) anophthalmus T \\
\hline & & DIPTERA & Sciaridae & unidentified, $\mathrm{T}$ \\
\hline & & & Trichoceridae & unidentified, $\mathrm{T}$ \\
\hline & & MUSCOMORPHA & & unidentified larva, $\mathrm{T}$ \\
\hline
\end{tabular}

${ }^{\star}$ Eggs, coccons and rests of undetermined taxa not included. ${ }^{\star \star}$ Parasitic.

In all the twelve drips we found 132 individuals and 67 eggs, respectively, belonging to 6 aquatic, 1 amphibious and 18 terrestrial invertebrate taxa (Table 2). Among these taxa, there are species which inhabit the hypogean, soil and epigean environments. Number of individuals was in significant positive correlation with $\mathrm{K}^{+}(r=0.64$, $p=0.026)$ and $\mathrm{NO}^{3-}(r=0.69, p=0.013)$. There were no correlation between the numbers of individuals, $D$, $H^{\prime}$, and the distance from the entrance and the surface $(p>0.05)$ in the dataset of all 12 drips. The $11^{\text {th }}$ drip is the output of a passage more or less directly connected with the surface. With respect to the presence there were no specific dispersion patterns neither in aquatic not in the terrestrial taxa therefore the Jaccard index dendrograms are not presented here. There were also no significant correlation between the values of the Jaccard index and it was also the case in the comparison of the aquatic against the terrestrial taxa $(r=-0.08$; Mantel t-test, $t=-0.54, p=$ 0.294). While the other taxa appeared in the drips more or less randomly, the only exception is the lumbricid species, present solely in drip No. 3 .

The most abundant taxa represented by ten or more individuals were oligochaetes from the families Enchytraeidae and Lumbricidae (Fig. 3), and eggs of undetermined organisms. Both the aquatic Enchytraeidae and amphibious Lumbricidae were the most abundant in the warm period of the year, while the newly-hatched enchytraeids were caught in January, after heavy raining. The 


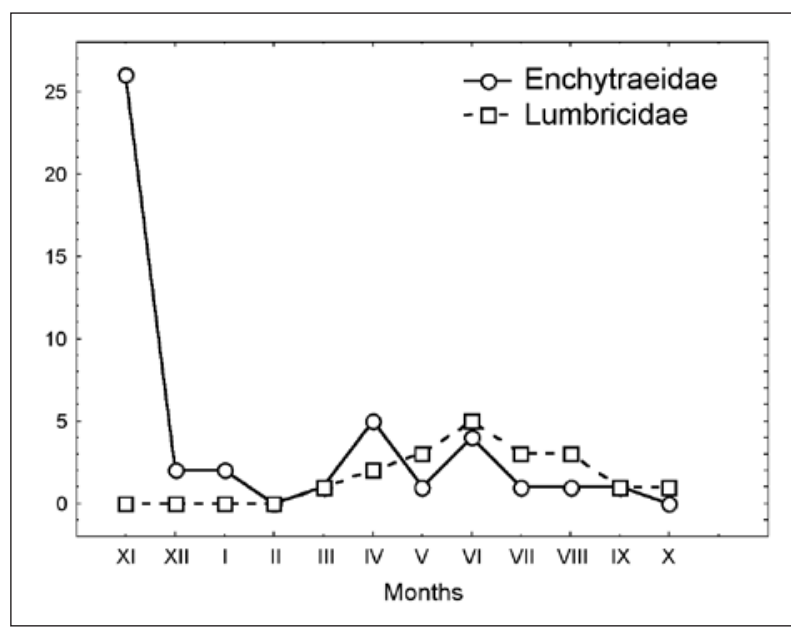

3: Oligochaeta were the most abundant in the drips in Huda luknja, sampling from November 2005 till October 2006.

lumbricid species, recently found also in half ripe guano, was present only in the drip No. 3 with the higher values of conductivity and concentrations of nitrates and chlorides (Table 1).

The concentration, $C=1-D$, and the ShannonWeaver diversity index, $H^{\prime}$, are presented in the Fig. 4. $D$

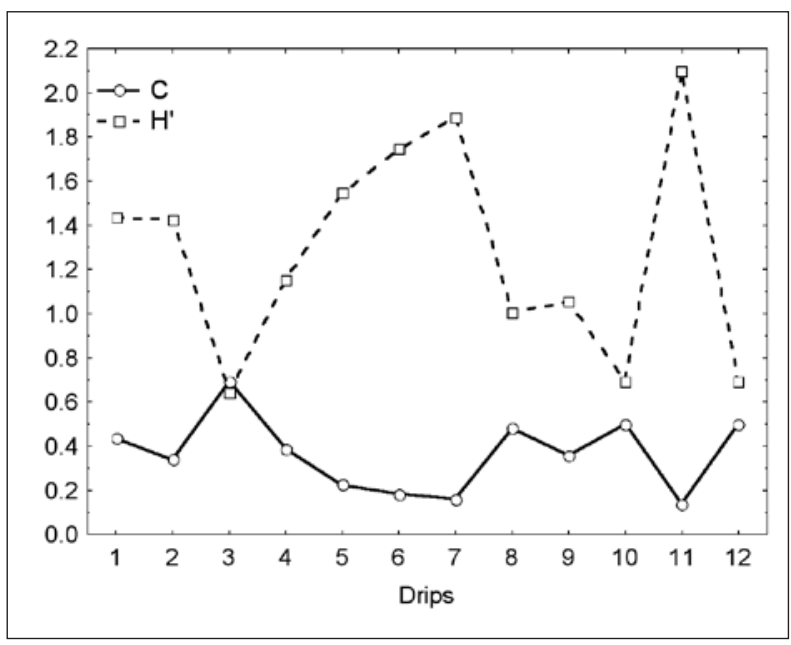

Fig. 4: Shannon-Weaver biodiversity index ( $\left.H^{\prime}\right)$ and concentration (C: 1-D) for each sampling site in Huda luknja from November 2005 till October 2006 (eggs not included).

and $H^{\prime}$ were in negative significant correlation with conductivity ( $D$ vs. conductivity: $\mathrm{r}=-0.77, p=0.004 ; H^{\prime}$ vs. conductivity: $r=-0.60, p=0.037$ ), and $D$ vs. total hardness $(r=-0.59, p=0.043)$ and $\mathrm{Ca}^{2+}(r=-0.61, p=0.037)$.

\section{DISCUSSION}

Comparison of an epikarst fauna from caves in Dinaric karst (SW Slovenia) and Huda luknja from isolated karst in NE Slovenia (Table 3) shows some important differences but also similarities. On the one hand, the karstic area with Huda luknja harbours relatively poor biodiversity, partly because the fauna in percolation water is not dominated by copepods as is the case in limestone caves in classical karst area (Pipan 2005). On the other hand, the finding of a new, probably endemic amphibious lumbricid species in the percolation water is a further indication of an isolated development of the fauna of the Paka isolated karst. The species found in the epikarst of Huda luknja are in sharp contrast to the results of Pipan (2005) in the epikarst of caves in the Dinaric karst region of Slovenia (Table 3). Copepod species diversity was negligible in Hudna luknja compared to the six karst caves. The smallest number of copepod species Pipan (2005) found was five and the median was eight, compared to two for Hudna luknja. This is unlikely the result of inadequate sampling. More drips were sampled in Huda luknja and Pipan and Culver (2007) showed that five or six drips should have been adequate to find 90 percent of the copepod species. Abundance differences of copepods tell the same story. Density per drip per year was many times less in Huda luknja than in any of the karst caves (Table 3). Only Postojnska jama approached Huda luknja in abundance and even there abundance was nearly three times greater. The abundance of other aquatic species shows a similar pattern although in this case Postojnska jama and Huda luknja form a group distinct from the other caves. What is the explanation for this difference? Pipan et al. (2006a) showed that ceiling thickness was an important determinant of species distribution, and the relative thick ceiling in Hudna luknja (see Fig. 1) would seem to bear this out, as does the negative correlation of overall abundance of animals with distance. The similar pattern was shown in the study of geographic distance on an epikarst copepod community composition in Organ Cave in West Virginia, U.S.A. (Pipan et al. 2006b).

The distribution of terrestrial species provides an important additional clue about structure of epikarst and a direction for future research. In striking contrast to the aquatic pattern, Huda luknja had more terrestrial individuals in the samples than the caves in Dinaric karst. As Pipan (2005) did not identify terrestrial animals to the same level of detail as in this study, it is not 
possible to compare species richness. Median number of terrestrial invertebrates per drip was 1.6 for the karst caves and 6.5 for Huda luknja (Table 3). This tantalizing data suggests that with increasing depth there may also be increasing amounts of terrestrial habitat. If it is the epikarst and not the column of percolating water that is the primary habitat as most evidence indicates (Culver \& Pipan 2005, but see Sket et al. 2004a), then the cracks and fissures of the zone of percolation harbors a terrestrial fauna (as indicated by presented data), and acts as a filter as indicated by the importance of ceiling thickness (Pipan et al. 2006a, b).

The distribution and the development of subterranean fauna depend on geomorphologic and hydrologic conditions since the Pliocene (Bole 1977). The idea that caves of various isolated karst patches could offer an opportunity for studying evolutionary and biogeographic processes in the hypogean fauna, especially molluscs (Bole 1972), has not been confirmed. It now seems that this idea can be resurrected by referring to the epikarst fauna. Distribution of fauna in the epikarst which is largely ruled by local conditions is in close relation with the hydrogeological characteristics of epikarst, controlled by hydraulic connectivity (Pipan \& Culver 2007). For some subterranean organisms it was found out that their reproduction is induced by decreasing temperature and increasing flux of organic material (Culver et al. 1995). We can assume that the enchytraeids with their newly hatched juveniles in November are representatives of such a species well adapted to the hypogean environments. The new lumbricid species, found only in the drip No. 3 whose water characteristics differed considerably from other drips especially by higher nitrate concentration, deserve a special treatment elsewhere. The positive correlation between number of individuals and $\mathrm{K}^{+}$and $\mathrm{NO}^{3-}$ probably concerns their special nutritional value, but any further conclusion would be speculative. Pipan et al. (2006a) discuss a similar example of exclusive presence among copepods in percolation water as some species were found only in one drip in a cave. This was best explained as representing extreme environmental conditions in the cave. Niphargus scopicauda probably derived from unknown water courses above the cave, while the two harpacticoid species are from the epikarst. Bryocamptus balcanicus shows troglomorphic characters while Parastenocaris nolli alpina with its slim body prefers interstitial habitats and crevices of the unsaturated zone where it most easily escapes from being preyed by various predators. It is often found in small depressions on cave walls but not in larger pools (Petkovski 1959, Pipan 2005). Groups of animals found in percolation water are common in many other subterranean habitats (Moldovan et al. 2007), but some stygobiotic species from drips are specialized for particular microhabitats and often represent endemic taxa (Pipan 2005). So far, perhaps except for the enchytraeid species, all the others in the Medvedji rov seem to belong to representatives of taxa sharing various habitats. Negative correlations of $D$ and $H^{\prime}$ with conductivity, and with total hardness and $\mathrm{Ca}^{2+}$ probably indicate that the individuals in drips were mostly eluted into the passage by water relatively rapidly percolating through the limestones, although this result could also be coincidental.

The significant differences in the physical and chemical properties between the drips indicate heterogeneous nature of the habitats supplying water to the drips. According to their terrestrial and aquatic taxa assemblages the drips are fed with the percolation water from the surface, from fissures and larger undiscovered passages above the Medvedji rov. In general, the epigean, epikarst and hypogean faunas were present in the drips, although fauna in the drips is relatively very poor as compared with the one in the Dinaric and Alpine karst (Pipan 2005; unpublished data), especially with respect to the phreatic taxa.

The biodiversity of a particular cave is governed by physical and ecological heterogeneity in the epikarst which influence the biotic diversity in the lower unsaturated zone (Pipan 2005, Moldovan et al. 2007). In principle, such taxa also present an important source of particulate organic carbon (POC) entering a cave through the epikarst (Simon at al. 2007). In our case, all three: the epigean, the epikarstic and the hypogean terrestrial as well as aquatic taxa contributed to the biotic diversity of the drips, but little to the input of organic matter. Subterranean biodiversity is at the local scale controlled by productivity (Gibert \& Deharveng 2002). The very limited amount of POC could be one of the reasons for the species scarcity in the area. The limited POC, the drifted individuals of terrestrial hypogean taxa as well as relatively low concentrations on $\mathrm{N}$ and $\mathrm{P}$ compounds in most drips suggest that sudden pouring with the rain water are the crucial factor for drifting fauna into the cave passage. The decrease of biodiversity from the first toward the last sampling site was found in some previous studies of an epikarst fauna from Slovenian caves (Pipan 2005, Pipan et al. 2006a), and as is the case in Medvedji rov indicates haphazardous influx of individuals from various habitats above the passage. 


\section{CONCLUSIONS}

On the basis of the fauna assemblages composed of terrestrial and aquatic taxa, it is concluded that samples from Huda luknja are fed by the percolation water from the surface, from fissures and larger undiscovered passages above the Medvedji rov. Both the aquatic as well as the terrestrial taxa were randomly distributed in the drips irrespective of the physical and chemical properties of water. In general, the epikarst aquatic fauna of the
Paka isolated karst is relatively poor. At the moment, it can not be concluded whether this is a general phenomenon in the isolated karst concerning its all-over biotic poverty or it is a specific characteristic of each isolated karst patches, like the Paka karst. More adequate knowledge on the topic must be acquired in the isolated karst to make the decision.

\section{ACKNOWLEDGEMENTS}

We are indebted to the staff of the chemical laboratory of the Steam Power Station Šoštanj where the chemical analyses were carried out, especially to Mrs. Greta Srnovršnik. We are grateful to the cavers of the Cavers' Club Speleos - Siga in Velenje for the support in the investigations and to Viktor Ocvirk for the help with the field work. Boris Sket and Cene Fišer determined the Niphargus specimens. We thank Janez Ravljen, Rajko Bračič and Milan Podpečan for the permission of publishing the plans of
Huda luknja. We sincerely thank Janez Mulec and David Culver for critical remarks and insightful comments on the manuscript. David Culver is thanked for his constructive review of the manuscript that included helpful suggestions and Table 3 that improved the value of the final paper. The study was partly supported by the Slovene Ministry of High Education, Science and Technology within the Biodiversity research programme (P1-0078).

\section{REFERENCES}

Bakalowicz, M., 2004: The epikarst, the skin of karst. In: Jones, W. K., D. C. Culver, \& J. S. Herman (eds.) Proceedings of the "Epikarst" Symposium, October 1-4, 2003, Sheperdstown, West Virginia, USA, Karst Waters Institute Special Publication 9, pp. 16-22.

Bole, J., 1972: Podzemeljski polži na osamljenem krasu Slovenije.- Naše jame, 13, 55-59.

Bole, J., 1977: Podzemeljski polži v osamljenem krasu Posavskega hribovja.- Naše jame, 18, 31-38.

Bole, J., 1985: Recentni podzemeljski polži in razvoj nekaterih porečij na dinarskem krasu.- Razprave (Dissertationes), classis IV, SAZU, 24, 315-328.

Brodar, M.,1993: Paleolitske in mezolitske najdbe iz jame Špehovke pri Zgornjem Doliču.- Arheološki vestnik, 44, 7-28.

Brodar, S., 1938: Das Paläolitikum in Jugoslawien.Quartär, 1, 140-172+VII.

Camacho, A. I., A. G. Valdecasas, J. Rodríguez, S. Cuezva, J. Lario, \& Sánchez-Moral, S., 2006: Habitat constraints in epikarstic waters of an Iberian Peninsula system cave.- Annales de Limnologie-International Journal of Limnology, 42, 2, 127-140.
Culver, D. C., T. C. Kane, \& Fong, D. W., 1995: Adaptations and natural selections in caves: the evolution of Gammarus minus.- Harvard University Press, p. 233, Cambridge.

Culver, D. C., M. C. Christman, W. R. Elliott, H. H. Hobbs III, \& Reddell J. R., 2003. The North American obligate cave fauna: regional patterns.- Biodiversity and Conservation, 12, 441-468.

Culver, D. C. \& Pipan, T., 2007: What does the distribution of stygobiotic Copepoda (Crustacea) tell us about their age?- Acta carsologica, 36, 87-91.

Culver, D. C. \& Pipan, T., in press: Caves as Islands.- In G. Rice [ed.] Encyclopedia of Islands, University of California Press, Berkeley.

Fong, D. W., D. C. Culver, H. H. Hobbs III, \& Pipan, T., 2007: The invertebrate cave fauna of West Virginia, Second edition.- West Virginia Speleological Survey, Bulletin No. 16, p. 163, Barrackville.

Gams, I., 2004: Kras v Sloveniji v prostoru in času.Inštitut za raziskovanje krasa ZRC SAZU, p. 515, Ljubljana. 
Gibert, J., \& Culver, D. C., 2002: Subterranean ecosystems: a truncated functional biodiversity.- Bioscience, 52, 6, 473-481.

Gospodarič, R., 1980: Geološka zgradba in kraški pojavi. In: Batič, F., M. Brodar, R. Gospodarič, V. Kuštor \& T. Novak: Soteska Huda luknja. Obzorja.- Kulturni in naravni spomeniki Slovenije, 102, 6-8.

Habe, F., 1972: Nekatere speleološke značilnosti osamljenega krasa Slovenije.- Naše jame, 13, 45-53.

Habič, P., 1969: Hidrografska rajonizacija krasa v Sloveniji.- Krš Jugoslavije, 6, 79-91.

Kocbek, F., 1895: Huda luknja in njene podzemeljske jame.- Planinski vestnik, 1(12), 177-181.

Legendre, P. \& Legendre, J., 2003: Numerical Ecology. Elsevier, Amsterdam.

Moldovan, O. T., T. Pipan, S. Iepure, A. Mihevc, \& Mulec, J., 2007: Biodiversity and ecology of fauna in percolating water in selected Slovenian and Romanian caves.- Acta carsologica, 36, 493-501.

Mršić, N., T. Novak, F. Potočnik \& Amon, T., 1996: Ecological evaluation of oniscoids and diplopods from cavities in Slovenia.- Mémoires de Biospéologie, 13, 203-210.

Novak, T., 2005: Terrestrial fauna from cavities in Northern and Central Slovenia, and a review of systematically ecologically investigated cavities.- Acta carsologica, 34, 169-210.

Novak, T. \& Kuštor, V., 1982: Zur Fauna der Wände dreier Höhlen Nordostsloweniens (Jugoslawien).- Die Höhle, 33(3), 82-89.

Petkovski, T. K., 1959: Fauna Copepoda pećine "Dona Duka” kod Rašča - Skopje.- Fragmenta balcanica, 2(14), 107-123.

Pipan, T., 2003: Ekologija ceponožnih rakov (Crustacea: Copepoda) v prenikajoči void izbranih kraških jam.- Doktorska disertacija (in Slovene with English abstract and summary), Univerza v Ljubljani, Oddelek za biologijo, p. 130, Ljubljana.

Pipan, T., 2005: Epikarst - A Promising Habitat. Copepod fauna, its diversity and ecology: a case study from Slovenia (Europe).- Karst Research Institute at ZRC SAZU, ZRC Publishing, p. 101, Postojna.

Pipan, T., \& Culver, D. C., 2005: Estimating biodiversity in the epikarstic zone of a West Virginia cave.- Journal of Cave and Karst Studies, 67(2), 103-109.

Pipan, T., A. Blejec, \& Brancelj, A., 2006a: Multivariate analysis of copepod assemblages in epikarstic waters of some Slovenian caves.- Hydrobiologia, 559, 213-223.

Pipan, T., M. C. Christman, \& Culver, D. C., 2006b: Dynamics of epikarst communities: microgeographic pattern and environmental determinants of epikarst copepods in Organ Cave, West Virginia.- American Midland Naturalist, 156, 75-87.

Pipan, T., \& Culver, D. C., 2007: Copepod distribution as an indicator of epikarst system connectivity.- Hydrogeology Journal, 15, 817-822.

Polscher, N., 1917: Die Huda luknja und ihre Grotten.Mitteilungen der Geographischen Gesellschaft in Wien, 60, 117-129.

Presetnik, P. \& Hudoklin, A., 2005: Spodnja Klevevška jama - pomembno zatočišče netopirjev in novo najdišče dolgokrilega netopirja (Miniopterus schreibersii) na Dolenjskem (JV Slovenija).- Natura Sloveniae, 7(1), 31-35.

Pretner, E., 1949: Aphaobius (Aphaobiella subgen. nov.) budnar-lipoglavšeki spec. nov, A. (A.) tisnicensis spec. nov. in opis samca Pretneria saulii G. Müller (Coleoptera, Silphidae).- Razprave (Dissertationes), classis IV, SAZU, 143-158.

Ravljen, J. (ur.), 1986: Soteska Huda luknja. Jamarski bilten. Glasilo jamarskega kluba 'Speleos' Titovo Velenje, 4-6.

Ravljen, J., 1989: Huda luknja nekoč in danes. Zbor štajerskih jamarjev Titovo Velenje, 3-10.

Simon, K. S., T. Pipan, \& Culver D. C., 2007: A conceptual model of the flow and distribution of organic carbon in caves.- Journal of Cave and Karst Studies, 69, 279-284.

Sket B., 1993. Cave fauna and speleobiology in Slovenia.Naše jame 35, 35-41.

Sket B., 1994. Distribution of some subterranean Crustacea in the territory of the former Yugoslavia.- Hydrobiologia 287, 65-75.

Sket B., 1999a. The nature of biodiversity in hypogean waters and how it is endangered.- Biodiversity and Conservation 8, 1319-1338.

Sket B., 1999b. High biodiversity in hypogean waters and its endangerment - the situation in Slovenia, the Dinaric karst, and Europe.- Crustaceana 72, 767-779.

Sket, B., 2002: The evolution of the karst versus the distribution and diversity of the hypogean fauna. In: Gabrovšek, F. (ed.) Evolution of karst: from prekarst to cessation, Inštitut za raziskovanje krasa ZRC SAZU, Založba ZRC, Postojna, pp. 225-232.

Sket, B., P. Trontelj, \& Žagar C., 2004a: Speleobiological characterization of the epikarst and its hydrological neighborhood: its role in dispersion of biota, its ecology and vulnerability, p. 104-113. In: Jones, W. K., D. C. Culver, \& Herman, J. S. (eds.) Epikarst. Proceedings of the symposium held October 1 through 4, 2003, Sheperdstown, West Virginia, USA, Karst Waters Institute Special Publ. 9, Charles Town, W.Va., pp. 104-113. 
Sket, B., K. Paragamian, \& Trontelj P., 2004b: A census of the obligate subterranean fauna of the Balkan Peninsula. In: Griffiths, H. I., B. Kryštufek, \& Reed, J. M. (eds.) Balkan Biodiversity. Pattern and Process in the European Hotspot, Kluwer Academic Publishers, Dordrecht, pp. 309-322.

SPSS 11.0 for Windows.

Standard Methods for the Examination of Water and Wastewater, $17^{\text {th }}$ edition, 1989.- APHA-AWWAWPCF, p. 1088 p.
Trontelj, P., Š. Gorički, S. Polak, R. Verovnik, V. Zakšek, \& Sket, B.,: 2007: Age estimates for some subterranean taxa and lineages in the Dinaric karst.- Acta carsologica, 36, 183-189.

Zagmajster, M. \& Kováč, L., 2006: Distribution of palpigrades (Arachnida, Palpigradi) in Slovenia with a new record of Eukoenenia austriaca (Hansen, 1926).- Natura Sloveniae, 8(1), 23-31. 
